https://doi.org/10.14295/revistadaesmesc.v28i34.p270

\title{
AS INFLUÊNCIAS DO PACOTE ANTICRIME NAS PROGRESSÕES DE REGIME
}

\section{THE INFLUENCES OF THE ANTI-CRIME PACKAGE ON REGIME PROGRESSIONS}

\section{Marcus Vinícius Fidélis Wagner Garbelotto ${ }^{1}$ Marília da Silva Araújo ${ }^{2}$}

Resumo: A presente pesquisa tem como objetivo analisar os novos requisitos objetivos para a progressão de regime inseridos na Lei de Execuções Penais por meio da Lei n. 13.964/2019, mais conhecida como "Pacote Anticrime". Antes da reforma, o ordenamento jurídico contava com quatro requisitos objetivos diferentes para concessão da progressão, a saber: (a) cumprimento de 1/6 (um sexto) da pena no regime anterior, nos casos de condenados por crimes comuns; (b) cumprimento de $2 / 5$ (dois quintos) da pena quando se tratar de crime hediondo, sendo primário o apenado; (c) cumprimento de 3/5 (três quintos) da pena quando o condenado a crime hediondo for reincidente; e (d) cumprimento de 1/8 (um oitavo) da pena no regime anterior quando se tratar de apenada gestante, mãe ou responsável por criança com deficiência, independente da condenação. Contudo, a Lei n. 13.964/2019 alterou o art. 112 da Lei de Execuções Penais, criando oito novos patamares para a concessão da benesse, além de manter aquele em relação a mulheres mães ou gestantes, sem se ater à realidade penitenciária no Brasil, em que há superlotação e falta de vagas em todos os estados da federação.

1. Bacharel em Direito pela Faculdade Estácio de Sá. Pós-graduando (especialização) em Direito Público, convênio entre a Universidade Regional de Blumenau (FURB) e a Escola Superior da Magistratura do Estado de Santa Catarina (ESMESC). Residente judicial. E-mail: marcusviniciusfwg@hotmail.com

2. Bacharel em Direito pela Universidade Federal de Santa Catarina. Pós-graduanda (especialização) em Direito e Processo Penal pela Academia Brasileira de Direito Constitucional. E-mail: mariliaaraujos@outlook.com 
Tal situação tende a piorar com os novos patamares previstos. Ademais, apesar do seu viés punitivista, o Pacote Anticrime incorreu em diversos erros legislativos, criando lacunas que, em alguns casos, beneficiam apenados. Por fim, acredita-se que a reforma também perdeu a oportunidade de pacificar diversos outros temas envolvendo a progressão de regime debatidos nos últimos anos e completamente ignorados pelo legislador.

Palavras-chave: Progressão de regime. Pacote Anticrime. Crimes hediondos. Sistema carcerário.

Abstract: This research aims to analyze the new objective requirements for the progression of regime included in the Criminal Execution Law through Law n. 13.964/2019, better known as the "Anti-Crime Package". Before the reform, the legal system had four different objective requirements for granting progression, namely: (a) fulfillment of $1 / 6$ (one sixth) of the sentence under the previous regime, in cases of those convicted of common crimes; (b) serving $2 / 5$ (two-fifths) of the penalty in the case of a heinous crime, the convict being primary; (c) fulfillment of $3 / 5$ (three-fifths) of the sentence when the person convicted of a heinous crime is a repeat offender; and (d) fulfillment of 1/8 (one eighth) of the penalty in the previous regime when dealing with a convicted pregnant woman, mother or guardian of a child with a disability, regardless of the conviction. However, Law n. 13.964/2019 amended article 112 of the Criminal Execution Law, creating eight new levels for the granting of the benefit, in addition to maintaining that in relation to mothers or pregnant women, without committing to the prison reality in Brazil, where there is overcrowding and shortages vacancies in all states of the federation. This situation tends to worsen with the new expected levels. Furthermore, despite its punitive bias, the Anti-Crime Package incurred several legislative errors, creating gaps that, in some cases, benefit offenders. Finally, it is believed that the reform also lost the opportunity to pacify several other issues involving regime progression debated in recent years and completely ignored by the legislator.

Keywords: Regime progression. Anti-crime package. Heinous crimes. Prison system. 


\section{INTRODUÇÃO}

A presente pesquisa tem como objetivo estudar os novos requisitos objetivos para concessão da progressão de regime a partir da promulgação da Lei n. 13.964/19. Antes da mencionada legislação, o ordenamento jurídico contava com quatro requisitos objetivos diferentes para concessão da progressão, quais sejam: (a) cumprimento de 1/6 (um sexto) da pena no regime anterior, nos casos de condenados por crimes comuns; (b) cumprimento de $2 / 5$ (dois quintos) da pena quando se tratar de crime hediondo, sendo primário o apenado; (c) cumprimento de $3 / 5$ (três quintos) da pena quando o condenado a crime hediondo for reincidente; e (d) cumprimento de 1/8 (um oitavo) da pena no regime anterior quando se tratar de apenada gestante, mãe ou responsável por criança com deficiência, independente da condenação.

Com o advento do Pacote Anticrime, o art. 112 da Lei de Execuções Penais foi substancialmente alterado, contando, dessa feita, com oito novos patamares para a concessão da benesse, além de manter aquele em relação a mulheres mães ou gestantes.

Malgrado o intento do legislador tenha sido recrudescer as progressões de regime, diferenciando as diversas situações processuais, sejam os acusados primários ou reincidentes, e o crime cometido, com ou sem violência, incorreu em diversas lacunas legislativas, permitindo que entendimentos não queridos fossem adotados por serem mais benéficos aos acusados/condenados, que devem ser solucionadas na esteira do que fora decidido pelo Superior Tribunal de Justiça no julgamento dos Recursos Especiais 1.910.240 e 1.918.338.

De outro norte, percebe-se que a legislação perdeu a oportunidade de positivar e sanar diversos outros imbróglios relativos às progressões de regime que geraram amplos debates no meio jurídico. Ademais, a lei ignorou o já saturado sistema penitenciário brasileiro, que se encontra em estado de superlotação, quadro este que tende a piorar.

O trabalho é dividido em cinco tópicos. O primeiro visa demonstrar, de forma sucinta, por meio de estudos históricos, o surgimento do sistema progressivo de cumprimento de pena. Já, no segundo tópico, 
pretende-se fazer uma ampla análise sobre a progressão de regime após a reforma da parte geral do Código Penal e a promulgação da Lei de Execuções Penais, abordando diversos aspectos controvertidos na doutrina e na jurisprudência. O terceiro tópico centra-se na Lei de Crimes Hediondos e seus reflexos nas progressões de regime. No quarto item, será explanado sobre as alterações legislativas ocorridas em benefício de apenadas mães ou gestantes. Por fim, no último ponto, serão abordados os novos requisitos objetivos para progressão de regime no Pacote Anticrime e suas adversidades.

\section{OS SISTEMAS PENITENCIÁRIOS QUE DERAM ORIGEM À PROGRESSÃO DE REGIME}

O movimento iluminista influenciou diversas esferas da arte e da ciência e intentou racionalizar o debate acerca da Justiça criminal da época, pela primeira vez levando-o ao campo filosófico. A partir do "Século das Luzes", a pena de prisão, que até então era utilizada apenas para resguardar o condenado até que sua sentença fosse executada, passou a ser adotada de forma mais irrestrita e como principal meio de punir um infrator.

Tornando-se a pena de prisão a principal forma de punição, a necessidade de estabelecimentos apropriados para resgate da pena tornou-se imperiosa. Nessa perspectiva, em 1790, nos Estados Unidos da América, surge um sistema de cumprimento de pena, o qual ficou conhecido como Sistema Pensilvânico ou Filadélfico, pois foi instalado na cidade de Filadélfia, Estado da Pensilvânia. Esse sistema baseava-se no total isolamento do apenado, que ficaria em uma cela orando. "Acreditava-se que, por meio da reflexão e da crença religiosa, aliadas à incomunicabilidade, era possível a recuperação do preso, que refletiria sobre seus erros" (CAMARGO, 2014, p. 21). PRADO (2017, p. 211) comenta que referido sistema foi posteriormente aperfeiçoado, "de forma que o condenado já podia manter contato com os diretores do presídio, os funcionários, médicos, religiosos, educadores, e, ainda, realizar pequenas tarefas". 
No mesmo período histórico, surgiu o sistema auburniano, na cidade de Auburn, Estado de Nova York. Nesse sistema, "os presos desenvolviam atividade laborais em suas próprias celas, permitindo-se, posteriormente, que tais trabalhos fossem desenvolvidos em grupos, durante o dia, desde que em silêncio" (PRADO, 2017, p. 212). Aqui, a principal ferramenta de recuperação do condenado era o trabalho, o que acabou se popularizando muito e tornou-se prática comum no sistema penitenciário atual.

Os dois sistemas são bastante parecidos, não havendo diferenças substanciais entre eles, pois "ambos defendiam a separação dos condenados, para impedir a comunicação e o isolamento noturno em celas individuais. No sistema filadélfico, porém, a segregação ocorria durante todo o dia, enquanto no auburniano permitia-se o trabalho coletivo por algumas horas" (PRADO, 2011, p. 646). Ademais, nenhum desses sistemas alcançou "êxito nos métodos empregados, o que acarretou o completo extermínio de suas concepções originais em algumas décadas" (PRADO, 2011, p. 646).

Contrapondo esses sistemas de origem norte-americana, os sistemasinglês e irlandês surgiram com uma proposta de progressão de regime. A autoria do sistema progressivo é compartilhada pelo inglês Alexander Maconochie e pelo irlandês Walter Crofton. Maconochie foi diretor da colônia penal da ilha de Norfolk, na Austrália, e "criou um sistema baseado em marcas (mark system), exposto em sua obra ThoughtsonConvict Management (1838), pelo qual o condenado poderia obter vales ou marcas conforme sua conduta e rendimento de seu trabalho" (PRADO, 2011, p. 646). Esse sistema de Maconochie contava com três etapas de cumprimento da pena, sendo o primeiro o isolamento de celular, o segundo a realização de trabalho intramuros com recolhimento noturno e o terceiro uma espécie de semiliberdade, na qual, cumpridas as condições, culminava em uma liberdade vigiada até findar a pena imposta. Por sua vez, Crofton aperfeiçoou o sistema de Maconochie, "acrescendo a ele uma fase intermediária, de semiliberdade, prévia a liberação do condenado, dirigida a adaptá-lo à vida social" (PRADO, 2011, p. 646-647). 
A redação original do nosso Código Penal, em 1940, já estabelecia uma espécie de progressão de regimes. MIRABETE (2014, p. 408) comenta a opção do legislador de 1940 ao adotar o sistema progressivo, prevendo "um período de isolamento absoluto por um prazo não superior a três meses na pena de reclusão, seguido de trabalho em comum durante o dia e da possibilidade de transferência para colônia penal ou estabelecimento similar, e afinal, o livramento condicional". Mas, foi apenas com a Lei n. 6.416, em 1977, que o sistema de progressões ficou melhor delineado como é conhecido hoje.

Com efeito, determinava o art. 30, $\S 5^{\circ}$, da Lei n. 6.416, de 1977, que “o condenado não perigoso, cuja pena não ultrapasse oito anos, poderá ser recolhido a estabelecimento de regime semi-aberto ( sic), desde o início, ou, se ultrapassar, após ter cumprido um terço dela em regime fechado" (BRASIL, 1977). Na sequência, o art. 30, § 5º, inciso I, determinava que, "se a pena não for superior a quatro anos, poderá ser recolhido a estabelecimento de regime aberto, desde o início, ou, a) se for superior a quatro até oito, após ter cumprido um terço em outro regime; b) se for superior a oito, após ter cumprido dois quintos em outro regime" (BRASIL, 1977).

Em 1984, uma grande onda reformista alterou toda a parte geral do Código Penal e criou a Lei de Execuções Penais, inexistente até então no ordenamento jurídico brasileiro. Tais mudanças, contudo, mantiveram o sistema progressivo de cumprimento de pena, dando novos ares ao tema ao disporem sobre requisitos e formas de concessão da benesse.

\section{A LEI DE EXECUÇÕES PENAIS, A REFORMA DO CÓDIGO PENAL DE 1984 E A PROGRESSÃO DE REGIME}

Como dito, na esteira de legislações anteriores, em 1984 foi promulgada a Lei n. 7.210/84, mais conhecida como Lei de Execuções Penais, bem como o Código Penal passou por uma ampla reforma na sua parte geral, mantendo, contudo, o sistema progressivo de penas. A própria exposição de motivos da Lei de Execuções Penais deixa claro a adoção do sistema progressivo de penas ao estabelecer que "as mudanças 
no itinerário da execução consistem na transferência do condenado de regime mais rigoroso para outro menos rigoroso (progressão) ou de regime menos rigoroso para outro mais rigoroso (regressão)", e também que "a progressão deve ser uma conquista do condenado pelo seu mérito e pressupõe o cumprimento mínimo de um sexto da pena no regime inicial ou anterior" (BRASIL, 1983).

Nessa perspectiva, o Código Penal passou a prever, após a ampla reforma operada em 1984, no seu art. $33, \S 2^{\circ}$, que "as penas privativas de liberdade deverão ser executadas em forma progressiva, segundo o mérito do condenado [...]" (BRASIL, 1984). Visando efetivar tal disposição, a Lei de Execuções Penais, em seu art.112, caput, inicialmente determinava que "a pena privativa de liberdade será executada em forma progressiva, com a transferência para regime menos rigoroso, a ser determinada pelo Juiz, quando o preso tiver cumprido ao menos 1/6 (um sexto) da pena no regime anterior e seu mérito indicar a progressão" (BRASIL, 1984). Assim, o condenado a uma pena de 12 (doze) anos, por exemplo, somente poderia pleitear a progressão ao regime semiaberto após o cumprimento de 2 (dois) anos no regime fechado.

Contudo, o cumprimento de 1/6 (um sexto) da pena, por si só, não bastava (e ainda não basta) para o deferimento da progressão de regime. Isso porque, além desse requisito de ordem objetiva, o apenado deveria cumprir outro de ordem subjetiva. Até 2003, o art. 112 contava com um parágrafo primeiro, o qual previa a elaboração de um exame criminológico e um parecer pela Comissão Técnica de Classificação antes da progressão de regime. A propósito, Avena (2019, p. 214) comenta que "tais elementos, sem dúvida, constituíam importante fonte de convencimento do julgador, permitindo-lhe uma análise global do preso a fim de verificar se estava ele apto a usufruir das benesses atinentes ao regime mais brando sem risco de tornar a delinquir".

Ocorre que o legislador de 1984 não previu as agruras do sistema penitenciário, o que dificultou a realização dos exames criminológicos ante a ausência de profissionais suficientes. Cintra (2021, p. 11) explica que a realização de tais exames poderia levar muitos meses, sendo que, em muitos casos, "a espera pelo exame criminológico superava o 
próprio requisito objetivo". De outro lado, Nucci (2021, p. 190) argumenta que a demora na realização do exame criminológico se dava, na verdade, por culpa dos governos estaduais, os quais não tinham intenção de "investir em número de funcionários para compor as diversas Comissões que seriam necessárias para um volume imenso de presos".

De todo modo, em 2003, o art. 112 da Lei de Execuções Penais foi alterado, passando a contar apenas com caput, o qual passou a dispor que:

Art. 112. A pena privativa de liberdade será executada em forma progressiva com a transferência para regime menos rigoroso, a ser determinada pelo juiz, quando o preso tiver cumprido ao menos um sexto da pena no regime anterior e ostentar bom comportamento carcerário, comprovado pelo diretor do estabelecimento, respeitadas as normas que vedam a progressão. (BRASIL, 2003).

Assim, a obrigatoriedade de realização do exame criminológico foi excluída da legislação, sendo substituída por mero atestado de bom comportamento carcerário a ser emitido pelo diretor do ergástulo prisional.

Com a nova disposição legal, passou-se a entender, por outro lado, que o exame criminológico ainda poderia ser realizado, tratando-se de uma faculdade do juiz da execução exigi-lo, e não mais uma obrigatoriedade, como o era anteriormente. O Superior Tribunal de Justiça consolidou tal entendimento com a Súmula n. 439, ao estatuir que "admite-se o exame criminológico pelas peculiaridades do caso, desde que em decisão motivada" (BRASIL, 2010). Em sentido similar, o Supremo Tribunal Federal, ao decidir sobre crimes hediondos, consignou, na Súmula vinculante n. 26, a possibilidade de se "[...] avaliar se o condenado preenche, ou não, os requisitos objetivos e subjetivos do benefício, podendo determinar, para tal fim, de modo fundamentado, a realização de exame criminológico" (BRASIL, 2006).

Assim, embora não seja um requisito expresso em lei, o exame criminológico é largamente aceito e realizado pelos estabelecimentos prisionais que detêm condições de realizá-lo, desde que sua requisição seja devidamente motivada pelo magistrado responsável, sob o argumento de que o juiz pode (e deve) buscar fundamentos para decidir, não se li- 
mitando ao atestado de bom comportamento concedido pelo diretor do estabelecimento prisional. Trata-se do livre convencimento motivado. Além disso, apontam alguns autores, não sem resistência de outros, que o exame criminológico coaduna-se com os fins da pena e a própria individualização da pena, este um princípio constitucional, pois "um dos princípios norteadores da execução penal gravita sobre a reeducação do condenado e a sua gradual reinserção social" (PRADO, 2017, p. 215).

Ainda sobre tal modificação legislativa, Marcão $(2019$, p. 66) formula contundente crítica à mera exigência de atestado de bom comportamento carcerário como requisito à progressão de regime ao comentar que "bom comportamento carcerário é o comportamento daquele que se põe de forma ajustada aos regramentos de disciplina do estabelecimento prisional", e, por isso, tal documento exime-se de analisar "propensão à reincidência, consciência e arrependimento quanto ao delito pelo qual foi recolhido preso".

Na mesma esteira, em 1983, Pimentel (1983, p. 158) já alertava que “ingressando no meio carcerário o sentenciado se adapta, paulatinamente, aos padrões da prisão", e o aprendizado desse indivíduo "é estimulado pela necessidade de se manter vivo e, se possível, ser aceito no grupo". Portanto, nos dizeres do autor, "longe de estar sendo ressocializado para a vida livre, está, na verdade, sendo socializado para viver na prisão". E, por esses motivos, "um observador desprevenido pode supor que um preso de bom comportamento é um homem regenerado, quando o que se dá é algo inteiramente diverso: trata-se apenas de um homem prisonizado" (PIMENTEL, 1983, p. 158).

À similitude, Avena (2019, p. 214) pontua que, ao adotar o entendimento de que o atestado de bom comportamento carcerário basta ao preenchimento do requisito subjetivo, "a competência para conceder o benefício ao encarcerado passaria a ser do diretor do estabelecimento prisional em que se encontrasse, e não mais do juiz da execução, uma vez que, diante de um atestado favorável, somente restaria ao julgador homologá-lo".

Como se não bastasse tais problemas envolvendo o requisito subjetivo para progressão de regime, na prática judicial, percebeu-se engo- 
do também quanto ao próprio requisito objetivo: trata-se do referencial para a segunda progressão. Ou seja, nas hipóteses em que o apenado inicia o cumprimento de sua pena no regime fechado, caso em que progredirá ao regime semiaberto após cumprido 1/6 (um sexto) da pena total imposta. Porém, a legislação não determina se, para a progressão ao regime aberto, deve o apenado cumprir mais 1/6 (um sexto) da pena total imposta ou apenas em relação à pena remanescente.

Malgrado subsistam entendimentos contrários, a corrente jurisprudencial majoritária consolidou entendimento pela necessidade de cumprimento de 1/6 (um sexto) da pena restante. Portanto, "se o indivíduo foi condenado a doze anos de reclusão em regime fechado e, após o cumprimento de dois anos (1/6 do total), obteve progressão para o regime semiaberto, poderá fazer jus a progressão para o regime aberto quando cumprir um ano e oito meses de pena (1/6 dos anos que restam a cumprir)" (AVENA, 2019, p. 212).

Sobre o ponto, Marcão (2019, p. 64) explica que tal entendimento jurisprudencial coaduna-se com as disposições legais sobre o tema, pois "pena cumprida é pena extinta, o que decorre, inclusive, de interpretação que se extrai do art. 113 do Código Penal", portanto, "tendo o condenado cumprido 1/6 (um sexto) de sua pena no regime anterior e obtido a progressão de regime, para a nova progressão deverá cumprir apenas 1/6 (um sexto) da pena restante, e não da pena total aplicada" (MARCÃO, 2019, p. 64).

Outro ponto interessante a se ressaltar acerca das progressões de regime é o entendimento jurisprudencial pela impossibilidade de conceder-se o benefício quando pendente pena de multa cumulativamente imposta, caso haja condições para seu efetivo pagamento. Isto é, tratando-se de apenado hipossuficiente, o não pagamento da multa não obstará a progressão, mas, em relação aos condenados que detenham boas condições financeiras, o pagamento deve ser realizado para que a progressão seja concedida. Esse entendimento passou a ser adotado a partir do julgamento, pelo Supremo Tribunal Federal, da Ação Penal n. 470, popularmente conhecida como "Mensalão". 
Por conseguinte, a Lei n. 10.763, de 2003, acresceu o parágrafo quarto ao art. 33 do Código Penal, prevendo que "o condenado por crime contra a administração pública terá a progressão de regime do cumprimento da pena condicionada à reparação do dano que causou, ou à devolução do produto do ilícito praticado, com os acréscimos legais" (BRASIL, 2003). Assim, criou-se um novo requisito para progressão de regime que, contudo, só deve ser aplicado a condenados por crimes contra a Administração Pública.

Marcão (2019, p. 65) concorda com esse entendimento, para quem a exigência de reparação do dano para a progressão de regime "constitui requisito objetivo específico ou especial, a ser exigido concomitantemente com os demais, apenas e tão somente quando envolver condenação por crime contra a administração pública, sem qualquer ressalva".

$\mathrm{O}$ autor destaca, ademais, a possibilidade de que outros problemas surjam a partir dessa previsão e comenta que "o benefício não poderá ser negado, por exemplo, quando o quantum da reparação depender, para sua apuração, de eventual liquidação de sentença” (MARCÃO, 2019, p. 65).

\section{A LEI DE CRIMES HEDIONDOS E O JULGAMENTO DO HABEAS CORPUS N. 82.959 PELO SUPREMO TRIBUNAL FEDERAL}

Em 1990, foi promulgada a Lei n. 8.072/90, a Lei de Crimes Hediondos, determinando, no seu art. $2^{\circ}, \S 1^{\circ}$, que "a pena por crime previsto neste artigo será cumprida integralmente em regime fechado" (BRASIL, 1990). Assim, aqueles condenados por crimes hediondos ou equiparados, diferentemente dos condenados por crimes comuns, não tinham direito à progressão de regime.

Contudo, boa parte da doutrina e da jurisprudência passou a apontar, de pronto, a inconstitucionalidade de tal disposição, pois feria, a um só tempo, o princípio da individualização da pena, previsto no art. $5^{\circ}$, inciso XLVI, da Constituição Federal, e a humanização da pena ao caracterizar-se como tratamento cruel ao condenado. 
Apontava-se, ainda, violação ao Pacto Internacional de Direitos Civis e Políticos, ratificado pelo Brasil em 1992, e que em seu art. $7^{\circ}$ vedava a submissão de qualquer povo à tortura ou "a penas ou tratamento cruéis, desumanos ou degradantes" (BRASIL, 1992).

Os debates foram inflamados em 1997, após a promulgação da Lei n. 9.455/1997, que definiu os crimes de tortura, equiparados à hediondo por opção constitucional (art. $5^{\circ}$ inciso XLIII, da Constituição Federal). Isso porque a legislação determinou, no art. $1^{\circ}, \S 7^{\circ}$, que "o condenado por crime previsto nesta Lei, salvo a hipótese do $\S 2^{\circ}$, iniciará o cumprimento da pena em regime fechado" (BRASIL, 1997).

Assim, o legislador ordinário conferiu tratamento mais benéfico ao condenado por crime de tortura do que aos demais apenados por crimes hediondos ou equiparados, já que a Lei n. 9.455/1997 permitia a progressão de regime para aqueles e não para estes. Portanto, muito se debateu, pois, "se isso pode ocorrer no caso de condenação pelo crime de tortura, a mesma solução deveria ser conferida em relação aos crimes hediondos e demais delitos a estes equiparados, já que todos receberam igual tratamento pelo art. 5, XLIII, da Constituição Federal” (AVENA, 2019, p. 216).

A fim de abalizar a controvérsia, o Supremo Tribunal Federal editou a Súmula n. 698 na qual entendeu que "não se estende aos demais crimes hediondos a admissibilidade de progressão no regime de execução da pena aplicada ao crime de tortura" (BRASIL, 2003).

Essa vedação à progressão prevista na Lei de Crimes Hediondos perdurou até fevereiro de 2006, quando, no julgamento do Habeas Corpus n. 82.959, o Supremo Tribunal Federal, em sessão plenária, por maioria, declarou a inconstitucionalidade do art. $2^{\circ}, \S 1^{\circ}$, da Lei n. 8.072/90 por violação ao princípio constitucional da individualização da pena.

Com esse entendimento, os condenados por crime hediondo ou equiparado passaram a se submeter à mesma disciplina legal que demais condenados no que se refere à progressão de regime, cujos requisitos estão previstos no art. 112 da Lei de Execuções Penais, quais sejam, cumprir 1/6 (um sexto) da pena no regime anterior e apresentar bom 
comportamento carcerário. A Súmula n. 698 do Supremo Tribunal Federal perdeu a sua eficácia.

Porém, a utilização de tais requisitos para progressão de regime igualmente violava a Constituição Federal, na medida em que esta conferiu aos crimes hediondos tratamento diverso dos crimes comuns (art. $5^{\circ}$, inciso XLIII). Assim, visando solucionar tal lacuna, em 29 de março de 2007, o legislador alterou o art. $2^{\circ}, \S 1^{\circ}$, da Lei de Crimes Hediondos para dispor que "a pena por crime previsto neste artigo será cumprida inicialmente em regime fechado" (BRASIL, 2007), e acrescentou um novo $\S 2^{\circ}$, determinando que "a progressão de regime, no caso dos condenados aos crimes previstos neste artigo, dar-se-á após o cumprimento de 2/5 (dois quintos) da pena, se o apenado for primário, e de $3 / 5$ (três quintos), se reincidente" (BRASIL, 2007).

Dessa forma, condenados a crimes hediondos deveriam apenas iniciar o cumprimento de pena em regime fechado, podendo, no entanto, progredirem a regime mais benéfico desde que cumpridos os patamares de 2/5 (dois quintos) da pena se primário, e de 3/5 (três quintos) se reincidente. Portanto, a legislação penal previa três requisitos objetivos diferentes para concessão da progressão de regime a depender do crime cometido e da reincidência do agente.

Ocorre que as novas frações previstas na lei de crimes hediondos, por serem mais graves aos réus/apenados, só tiveram aplicação para crimes cometidos após a promulgação da Lei n. 11.464/07, que os inseriu na Lei de Crimes Hediondos, à vista do princípio da irretroatividade da lei maléfica, disposto no art. 5, inciso XL, da Constituição Federal, "a lei penal não retroagirá, salvo para beneficiar o réu” (BRASIL, 1988).

Esse foi, inclusive, o entendimento sedimentado pelo Superior Tribunal de Justiça na Súmula n. 471: “Os condenados por crimes hediondos ou assemelhados cometidos antes da vigência da Lei n. 11.464/2007 sujeitam-se ao disposto no art. 112 da Lei n. 7.210/1984 (Lei de Execução Penal) para a progressão de regime prisional" (BRASIL, 2011).

Os diversos problemas relacionados à imposição de regime aos crimes hediondos, bem como a progressão destes, no entanto, ainda estão longe de ser superados. Exemplo disso foi a declaração de inconstitu- 
cionalidade, pelo Supremo Tribunal Federal, da nova redação do art. $2^{\circ}$, $\S 1^{\mathrm{o}}$, da Lei n. 8.072/90.

Como visto, após o Supremo Tribunal Federal declarar inconstitucional a impossibilidade de progressão de regime no julgamento do Habeas Corpus n. 82.959, o legislador ordinário reformou a Lei de Crimes Hediondos para impor regime inicial fechado aos crimes classificados como hediondos, além de prever novas frações de progressão.

Contudo, parte da doutrina e da jurisprudência passou a entender que a nova redação também era inconstitucional, pois determinava aplicação do regime inicial fechado independentemente do quantum de pena. Sobre isso, Marcão (2019, p. 62) comenta que o regime fechado era imposto "sem outros questionamentos em linhas de individualização, de modo a tolher a atividade individualizatória conferida ao Poder Judiciário, e malferir garantia fundamental do acusado, assegurada no art. $5^{\circ}$, XLVI, da Constituição Federal".

Após amplos debates da comunidade jurídica, o tema chegou, novamente, ao Plenário do Supremo Tribunal Federal, em junho de 2012, por meio do Habeas Corpus n. 111.840/ES. Nessa oportunidade, o Tribunal entendeu que a imposição de regime inicial fechado com base exclusivamente no fato de ser o crime hediondo, igualmente viola a individualização da pena. Como tal entendimento é benéfico em relação a quem já cometeu o crime, pode ele retroagir para beneficiar apenados por crimes hediondos. Nesses casos, "faz-se imprescindível verificar se o regime inicial fora fixado tão somente com base no dispositivo em testilha e, sendo caso, proceder-se ao ajuste do regime em sede de execução" (MARCÃO, 2019, p. 62).

Porém, apesar da declaração de inconstitucionalidade pelo Supremo Tribunal Federal, ante a plena vigência do dispositivo em voga, já que a eficácia não foi suspensa pelo Senado Federal (ex vi art. 52, inciso X, da Constituição Federal), o regime inicial fechado ainda é imposto em muitos casos a condenados por crimes hediondos.

Em relação a condenações por crimes hediondos ou equiparados, o operador do direito há que se atentar, ainda, à possibilidade de coexis- 
tência de múltiplas condenações, por crimes comuns e hediondos, com ou sem reincidência.

Com efeito, o art. 111 da Lei de Execuções Penais determina que, havendo condenação por mais de um crime, "a determinação do regime de cumprimento será feita pelo resultado da soma ou unificação das penas, observada, quando for o caso, a detração ou remição" (BRASIL, 1984). Assim, se determinado indivíduo é condenado a uma pena de 06 (seis) anos pela prática de um crime comum e 10 (dez) anos por crime hediondo ou equiparado, reconhecida aqui sua reincidência, terá um total de 16 (dezesseis) anos de pena a cumprir.

Contudo, para progressão de regime, "deve-se atender às duas necessidades, quanto ao hediondo, que se cumpre em primeiro lugar e, também, quanto ao comum. Atingido o prazo do hediondo, deve-se imediatamente começar a computar o prazo do comum. Tal cálculo em separado possui respaldo jurisprudencial"' (NUCCI, 2021, p. 193). Nesse exemplo, portanto, após cumprido 6 (seis) anos no regime fechado, o apenado terá atingido o patamar de $3 / 5$ (três quintos) para a progressão de regime em relação ao crime hediondo (pois reincidente), mas deverá cumprir mais 1 (um) ano no regime mais severo ante sua condenação também por crime comum, no qual se aplica o quantum de 1/6 (um sexto). Nessa perspectiva, após cumpridos 7 (sete) anos no regime fechado, poderá o condenado pleitear pela progressão de regime, desde que preenchidos demais requisitos.

\section{AS ALTERAÇÕES LEGISLATIVAS OCORRIDAS EM BENEFÍCIO DE APENADAS MÃES OU GESTANTES}

De outro lado, em relação às apenadas que são mães, gestantes ou responsáveis por pessoas com deficiência, a jurisprudência e as próprias mudanças legislativas passaram a adotar entendimentos mais liberatórios a fim de resguardar essas pessoas que necessitam de cuidados.

Assim, a partir da maior atenção que os poderes públicos passaram a dar à situação de mulheres encarceradas, sobretudo aquelas que são mães ou gestantes, diversas disposições legislativas e entendimentos 
jurisprudências foram construídos a fim de atender às demandas de tais mulheres, sempre visando a proteção dos infantes, como foi o caso da promulgação da Lei n. 13.257/2016 (Estatuto da Primeira Infância), e o julgamento do Habeas Corpus coletivo n. 143.641/SP pelo Supremo Tribunal Federal, em fevereiro de 2018.

Seguindo tal raciocínio, em dezembro de 2018, a Lei n. 13.769/18 inseriu os parágrafos terceiro e quarto ao art. 112 da Lei de Execução Penal, prevendo uma nova modalidade de progressão de regime, conhecida como progressão especial. Nela, a mulher gestante ou que for mãe ou responsável por crianças ou pessoas com deficiência poderá progredir após o cumprimento de apenas $1 / 8$ (um oitavo) da pena no regime anterior, além de preencher outros requisitos, quais sejam: não ter cometido crime com violência ou grave ameaça à pessoa, nem contra seu filho ou dependente; ser primária; ter bom comportamento carcerário; e não integrar organização criminosa.

Além desses requisitos legais (porque previstos em lei), a jurisprudência catarinense consolidou entendimento pela necessidade de preenchimento de um requisito a mais, de caráter subjetivo, consistente na imprescindibilidade da genitora para o cuidado dos filhos. Tal requisito se justifica na medida em que a progressão especial foi criada pelo legislador infraconstitucional com intuito de proteger o infante ainda em desenvolvimento e não conceder uma progressão diferenciada à mulher pelo simples fato de ser mãe, o que destoaria da razoabilidade.

Destaque-se, ademais, que tal benéfica fração, mantida pelo Pacote Anticrime, adiante-se, "deve ser observada, mesmo em se tratando de crimes hediondos e equiparados", pois "a Lei 13.769/18 alterou a redação do art. $2^{\circ}, \S 2^{\circ}$, da Lei 8.072/90, que manda observar, para estas

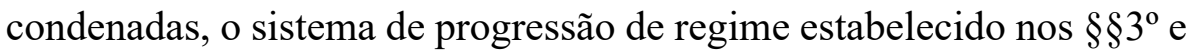

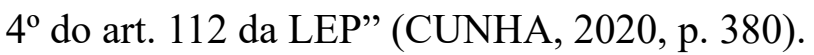

\section{OS NOVOS REQUISITOS OBJETIVOS PARA PROGRESSÃO DE REGIME NO PACOTE ANTICRIME}

Em junho de 2018, o Projeto de Lei n. 10.372/2018 foi proposto na Câmara dos Deputados prevendo diversas alterações no sistema de jus- 
tiça criminal brasileiro, contemplando desde o Código Penal e o Código de Processo Penal à Lei de Execuções Penais. No Senado Federal, o projeto recebeu o número 6.341/2019 e, depois, culminou na Lei $\mathrm{n}^{\mathrm{o}}$ 13.964/19, popularmente conhecida como "Pacote Anticrime". Entre as diversas modificações introduzidas no sistema de justiça brasileiro, as que interessam para a presente pesquisa são aquelas concernentes às alterações no art. 112 da Lei n. 7.210/84, pois dizem respeito, justamente, sobre as progressões de regime.

Até então, o requisito objetivo para progressão de regime baseava-se, como visto, em frações, contudo elas foram descartadas pelo legislador reformador, que as substituiu por oito diferentes percentuais de cumprimento de pena, quais sejam: (i) 16\% (dezesseis por cento) da pena, se o apenado for primário e o crime tiver sido cometido sem violência à pessoa ou grave ameaça; (ii) $20 \%$ (vinte por cento) da pena, se o apenado for reincidente em crime cometido sem violência à pessoa ou grave ameaça; (iii) $25 \%$ (vinte e cinco por cento) da pena, se o apenado for primário e o crime tiver sido cometido com violência à pessoa ou grave ameaça; (iv) 30\% (trinta por cento) da pena, se o apenado for reincidente em crime cometido com violência à pessoa ou grave ameaça; (v) 40\% (quarenta por cento) da pena, se o apenado for condenado pela prática de crime hediondo ou equiparado, se for primário; (vi) 50\% (cinquenta por cento) da pena, se o apenado for: a) condenado pela prática de crime hediondo ou equiparado, com resultado morte, se for primário, vedado o livramento condicional; b) condenado por exercer o comando, individual ou coletivo, de organização criminosa estruturada para a prática de crime hediondo ou equiparado; ou c) condenado pela prática do crime de constituição de milícia privada; (vii) 60\% (sessenta por cento) da pena, se o apenado for reincidente na prática de crime hediondo ou equiparado; e (viii) 70\% (setenta por cento) da pena, se o apenado for reincidente em crime hediondo ou equiparado com resultado morte, sendo vedado, neste último caso, o livramento condicional.

Cabe registrar que, além desses novos percentuais, foi mantida, no ordenamento, a progressão de regime especial, destinada a mulheres gestantes, mães ou responsáveis por crianças com deficiência. Portan- 
to, a partir da alteração, a legislação executória penal conta com nove quantuns distintos de progressão de regime.

Outrossim, por prever requisitos objetivos, em sua maioria mais gravosos aos apenados, a novel legislação somente poderá ser aplicada, nesses casos, àqueles que forem condenados por crime cometido após a vigência da nova lei. É dizer: os três requisitos anteriores à reforma $(1 / 6,2 / 5$ e $3 / 5)$ continuam vigentes e devem ser aplicados, quando mais benéficos aos apenados. Assim, "as execuções penais que reúnam condenações por crimes cometidos antes e depois da entrada em vigor da Lei $\mathrm{n}^{\mathrm{o}}$ 13.964/19 desafiarão, portanto, cálculo diferenciado para fins de progressão de regime" (SANTOS, 2020, p. 443).

De outro lado, a existência de lacunas legislativas possibilitou interpretações no sentido de que alguns novos patamares devem ser considerados benéficos aos apenados, como é o caso dos incisos V e VII, que versam sobre a prática de crime hediondo.

Com efeito, o art. $2^{\circ}, \S 2^{\circ}$, da Lei de Crimes Hediondos determinava a aplicação da fração de $3 / 5$ a condenados por crimes hediondos que fossem reincidentes, sem especificar de que espécie de reincidência se tratava. Portanto, prevalecia o entendimento de que não era necessária a reincidência específica para aplicação da fração mais grave, bastando tratar-se de réu já anteriormente condenado em definitivo, por qualquer delito.

Ocorre que o Pacote Anticrime revogou expressamente o art. $2^{\circ}, \S$ $2^{\circ}$, da Lei n. 8.072/90, passando a submeter a progressão de regime em crimes hediondos apenas ao art. 112 da Lei de Execuções Penais. Como visto, a nova legislação determina a aplicação do patamar de $40 \%$ (quarenta por cento), equivalente a $2 / 5$ (dois quintos), aos condenados pela prática de crime hediondo ou equiparado, se primário; e a aplicação de $60 \%$ (sessenta por cento), equivalente a $3 / 5$ (três quintos), "se o apenado for reincidente na prática de crime hediondo ou equiparado" (BRASIL, 2019, grifo nosso). Ou seja, pela sua atual redação, o art. 112, inciso VII, determina a aplicação do patamar mais gravoso apenas ao reincidente específico em crime hediondo. 
Por esse motivo, após uma resistência inicial, o Tribunal de Justiça de Santa Catarina passou a adotar o entendimento de que, após as alterações da Lei n. 13.964/19, a reincidência exigida para aplicação de $60 \%$ deve ser específica em crimes da mesma natureza e, inexistindo previsão legal de qual patamar a ser utilizado para reincidentes genéricos, deve-se aplicar a interpretação mais benéfica (40\%), como se primário fosse.

Tal entendimento coaduna-se com o recente julgamento dos Recursos Especiais 1.910.240 e 1.918.338 pela Terceira Seção do Superior Tribunal de Justiça, no qual a Corte fixou entendimento, à unanimidade, de que a lacuna legislativa deve ser interpretada em favor de apenados/réus, assentando a seguinte tese: "É reconhecida a retroatividade do patamar estabelecido no art. 112, V, da Lei n. 13.964/2019, àqueles apenados que, embora tenham cometido crime hediondo ou equiparado sem resultado morte, não sejam reincidentes em delito de natureza semelhante" (BRASIL, 2021).

A partir desse entendimento, o Superior Tribunal de Justiça assinalou o caminho a ser seguido para as demais brechas legislativas. Isso porque essa lacuna envolvendo crimes hediondos não foi a única presente no art. 112 da Lei de Execuções Penais, embora seja a que recebeu maior atenção por tratar da possibilidade de retroatividade da Lei.

Com efeito, "a intenção do legislador foi distinguir o primário do reincidente, a depender da natureza do delito, sem ou com violência ou grave ameaça à pessoa" (SANTOS, 2020, p. 443). Contudo, ante a infeliz redação, a mesma lacuna legislativa é observada no inciso IV do referido dispositivo legal, ao determinar a aplicação de "30\% (trinta por cento) da pena, se o apenado for reincidente em crime cometido com violência à pessoa ou grave ameaça" (BRASIL, 2019, grifo nosso), ou seja, versa sobre o reincidente específico, "logo, malgrado o delito objeto da condenação envolver violência ou grave ameaça à pessoa, caso o título condenatório pretérito ensejador da reincidência verse sobre injusto sem violência nem grave ameaça à pessoa, cumpre observar o percentual de $25 \%$ em vez de 30 " (SANTOS, 2020, p. 443). 
À similitude, o inciso VIII determina que o apenado cumpra 70\% (setenta por cento) da pena, se for reincidente em crime hediondo ou equiparado com resultado morte. A redação é clara ao condicionar tal elevada progressão apenas aos reincidentes específicos em crime hediondo com resultado morte. Nesse viés, tratando-se de condenado a crime hediondo com resultado morte, com reincidência em crime hediondo sem resultado morte (reincidente não específico), há nova lacuna legislativa. Entende-se que o percentual a ser utilizado deve ser o de $60 \%$ (sessenta por cento), previsto no inciso VII, pois trata de reincidentes em crimes hediondos. Contudo, é importante se atentar ao inciso VI, alínea "a", que determina a progressão em $50 \%$ (cinquenta por cento) quando o apenado for "condenado pela prática de crime hediondo ou equiparado, com resultado morte, se for primário" (BRASIL, 2019).

Essa lacuna permite "o surgimento de posição no sentido de, uma vez descartado o inciso VIII, haveria de ser observado, a contrario sensu, o percentual de $50 \%$, porque concernente a crimes da mesma natureza - hediondos ou afins, com morte" (SANTOS, 2020, p. 446). Contudo, pensa-se que a melhor interpretação é aquela que determina a aplicação de $60 \%$ (sessenta por cento).

Outro defeito legislativo diz respeito à progressão de regime versus livramento condicional aos condenados pela prática do crime de constituição de milícia privada. Isso porque o art. 112, inciso VI, alínea "c", prevê o cumprimento de 50\% (cinquenta por cento) da pena para concessão da progressão de regime. Entretanto, por não ser crime hediondo, o livramento condicional pode ser concedido após o cumprimento de 1/3 (um terço) da pena, se primário, e 1/5 (um quinto), se reincidente, nos moldes do art. 83 do Código Penal. Assim, "o direito mais expressivo, livramento condicional, é conquistado (bem) antes, se primário, ou em tempo igual, se reincidente, ao reservado à progressão de regime, em total afronta à cláusula constitucional concernente à individualização da pena (art. 5, XLVI, da CRFB/88)" (SANTOS, 2020, p. 447).

É de se notar, portanto, que, apesar do intento punitivista, o legislador ordinário reformador não se atentou às imprecisões do novo texto 
legal, permitindo que entendimentos não queridos fossem adotados, desde já, a condenado por crimes hediondos, por serem mais benéficos. À similitude, ante a imprecisão técnica, criou diversas lacunas legais, as quais devem ser solucionadas seguindo o mesmo caminho trilhado pelo Superior Tribunal de Justiça no julgamento dos Recursos Especiais 1.910 .240 e 1.918 .338 .

Não bastasse, denota-se que o Pacote Anticrime eximiu-se de positivar diversos outros temas relativos às progressões de regime que geraram amplos debates no meio jurídico, tais como a (im)possibilidade de fixação de regime inicial fechado aos condenados por crime hediondos, o referencial a ser considerado na segunda progressão de regime, a viabilidade de realização do exame criminológico e a necessidade de pagamento da multa como requisito para concessão da progressão.

Por fim, não há como se ignorar a completa ausência de preocupação com o sistema penitenciário brasileiro, o qual já se encontra em estado de superlotação, quadro este que tende a piorar com a Lei n. $13.964 / 2019$.

\section{CONCLUSÃO}

Como visto, antes da entrada em vigor do Pacote Anticrime, o ordenamento jurídico contava com quatro requisitos objetivos diferentes para concessão da progressão, a saber: (a) cumprimento de 1/6 (um sexto) da pena no regime anterior, nos casos de condenados por crimes comuns; (b) cumprimento de $2 / 5$ (dois quintos) da pena quando se tratar de crime hediondo, sendo primário o apenado; (c) cumprimento de $3 / 5$ (três quintos) da pena quando o condenado a crime hediondo for reincidente; e (d) cumprimento de 1/8 (um oitavo) da pena no regime anterior quando se tratar de apenada gestante, mãe ou responsável por criança com deficiência, independente da condenação.

A Lei n. 13.964/19, por sua vez, alterou o art. 112 da Lei de Execuções Penais, criando oito novos patamares para a concessão da benesse, além de manter aquele em relação a mulheres mães ou gestantes, sem 
se ater, contudo, à realidade penitenciária no Brasil, em que há superlotação e falta de vagas em todos os estados da federação.

De acordo com o Levantamento Nacional de Informações Penitenciárias - Infopen, publicado em dezembro de 2019, com dados de julho a dezembro do mesmo ano, o Brasil conta com uma população carcerária de 748.009 (setecentos e quarenta e oito mil e nove) pessoas. Contudo, existem apenas 442.349 (quatrocentos e quarenta e dois mil e trezentos e quarenta e nove) vagas, ou seja, há um déficit de 305.660 (trezentos e cinco mil e seiscentos e sessenta) vagas (BRASIL, 2019).

Se analisar apenas os dados relativos a presos no regime fechado, o relatório demonstra a existência de 362.547 (trezentos e sessenta e dois mil e quinhentos e quarenta e sete) pessoas encarceradas e apenas 203.107 (duzentos e três mil e cento e sete) vagas, atestando, igualmente, enorme contingente populacional acima da capacidade, com superlotação de 159.440 (cento e cinquenta e nove mil e quatrocentos e quarenta) pessoas além das vagas (BRASIL, 2019).

Por essa e outras razões, em 2015, na Ação de Descumprimento de Preceito Fundamental n. 347, o Supremo Tribunal Federal declarou o Estado de Coisas Inconstitucional do sistema penitenciário brasileiro, situação que demonstra o desvio de finalidade da execução penal no Brasil. "As funções declaradas da pena são incompatíveis com o que se assiste na prática”, pois "o cárcere é verdadeiro espaço de gestão de corpos de pessoas majoritariamente negras, com baixa instrução escolar, pobres e jovens" (ASSUMPÇÃO, 2020, p. 147).

Com isso em consideração, embora a Lei n. 13.964/2019 intente fazer distinções mais específicas para a progressão de regime, adotando "um modelo mais compatível com a pluralidade de pessoas apenadas e de infrações cometidas", atentando-se ao princípio da isonomia, "a forma de corrigir essa eventual distorção não nos pareceu minimamente razoável, adequada ou proporcional, ao menos em algumas das situações”. (ASSUMPÇÃO, 2020, p. 149/150).

Isso porque, com os novos marcos objetivos para concessão da progressão de regime, o Pacote Anticrime demonstra seu escopo em "manter os indivíduos presos por mais tempo em um local reconhecido como 
sendo constante violador de direitos humanos, como já declarado pelo Supremo Tribunal Federal na ADPF 347" (MENDES; MARTÍNEZ, 2020, p. 184). Assim, crê-se que um "brutal encarceramento inescapavelmente advirá com a Lei no 13.964/19”' (SANTOS, 2020, p. 453).

Outrossim, entende-se que, além de ignorar a realidade penitenciária, a novel legislação eximiu-se de positivar diversos outros temas relativos às progressões de regime que geraram amplos debates no meio jurídico ao longo dos anos, bem como, ante sua imprecisão técnica, criou diversas lacunas legislativas, as quais devem ser interpretadas em favor dos acusados/apenados.

\section{REFERÊNCIAS}

ASSUMPÇÃO, Vinícius. Pacote anticrime: comentários à lei n. 13.964/2019. São Paulo: Saraiva Educação, 2020.

AVENA, Norberto. Execução penal. 6. ed. Rio de Janeiro: Forense; São Paulo: MÉTODO, 2019.

BRASIL. [Constituição (1988)]. Constituição da República Federativa do Brasil de 1988. Brasília, DF: Presidência da República, 1988. Disponível em: Constituição da República Federativa do Brasil de 1988. Acesso em: 28 jun. 2021.

BRASIL. Decreto n. 592 de 06 de julho de 1992. Atos Internacionais. Pacto Internacional sobre Direitos Civis e Políticos. Promulgação. Brasília, DF: Presidência da República, 1992. Disponível em:http://www. planalto.gov.br/ccivil_03/decreto/1990-1994/d0592.htm. Acesso em: 28 jun. 2021.

BRASIL. Decreto-lei $\mathbf{n}^{\mathbf{2}} \mathbf{2 . 8 4 8}$, de 7 de dezembro de 1940. Código Penal. Brasília, DF: Presidência da República, 1940. Disponível em: http://www.planalto.gov.br/ccivil_03/decreto-lei/del2848compilado. htm. Acesso em: 28 jun. 2021.

BRASIL. Exposição de Motivos da Lei de Execuções Penais. Lei n. ${ }^{\circ}$ 7.210, de 11 de julho de 1984, de 11 de julho de 1984. Disponível em:https:/www2.camara.leg.br/legin/fed/lei/1980-1987/lei-7210-11-julho- 
-1984-356938-exposicaodemotivos-149285-pl.html. Acesso em: 29 jun. 2021.

BRASIL. Lei n. ${ }^{\circ}$ 6.416, de 24 de maio de 1977. Altera dispositivos do Código Penal (Decreto-lei número 2.848, de 7 de dezembro de 1940), do Código de Processo Penal (Decreto-lei número 3.689, de 3 de outubro de 1941), da Lei das Contravenções Penais (Decreto-lei número 3.688, de 3 de outubro de 1941), e dá outras providências. Brasília, DF: Presidência da República, 1977. Disponível em:http://www.planalto. gov.br/ccivil_03/leis/16416.htm. Acesso em: 28 jun. 2021.

BRASIL. Lei n. ${ }^{0}$ 7.209, de 11 de julho de 1984. Altera dispositivos do Decreto-Lei no 2.848, de 7 de dezembro de 1940 - Código Penal, e dá outras providências. Brasília, DF: Presidência da República, 1984. Disponível em:http://www.planalto.gov.br/ccivil_03/leis/1980-1988/ 17209.htm. Acesso em: 28 jun. 2021.

BRASIL. Lei n. ${ }^{\circ}$ 7.210, de 11 de julho de 1984. Institui a Lei de Execução Penal. Brasília, DF: Presidência da República, 1984. Disponível em:http://www.planalto.gov.br/ccivil_03/leis/17210.htm. Acesso em: 28 jun. 2021.

BRASIL. Lei n. ${ }^{\circ}$ 8.072, de 25 de julho de 1990. Dispõe sobre os crimes hediondos, nos termos do art. $5^{\circ}$, inciso XLIII, da Constituição Federal, e determina outras providências. Brasília, DF: Presidência da República, 1990. Disponível em: http://www.planalto.gov.br/ccivil_03/ leis/18072.htm. Acesso em: 28 jun. de 2021.

BRASIL. Lei n. 9.455, de 07 de abril de 1977. Define os crimes de tortura e dá outras providências. Brasília, DF: Presidência da República, 1977. Disponível em:http://www.planalto.gov.br/ccivil_03/leis/ 19455.htm. Acesso em: 28 jun. 2021.

BRASIL. Lei n. ${ }^{\circ}$ 10.763, de 12 de novembro de 2003. Acrescenta artigo ao Código Penal e modifica a pena cominada aos crimes de corrupção ativa e passiva. Brasília, DF: Presidência da República, 2003. Disponível em:http:/www.planalto.gov.br/ccivil_03/leis/2003/ 110.763.htm\#: :text=L10763\&text $=$ LEI $\% 20 \mathrm{No} \% 2010.763 \% 2 \mathrm{C} \% 20$ 
DE,de \%20corrup \%C3\%A7\%C3\%A3o\%20ativa\%20e\%20passiva. Acesso em: 28 jun. 2021.

BRASIL. Lei n. ${ }^{\circ}$ 10.792, de 1 de dezembro de 2003. Altera a Lei no 7.210, de 11 de junho de 1984 - Lei de Execução Penal e o Decreto-Lei no 3.689, de 3 de outubro de 1941 - Código de Processo Penal e dá outras providências. Brasília, DF: Presidência da República, 2003. Disponível em:http://www.planalto.gov.br/ccivil_03/leis/2003/L10.792. htm\#art112. Acesso em: 28 jun. 2021.

BRASIL. Lei n. ${ }^{\circ}$ 11.464, de 28 de março de 2007. Dá nova redação ao art. 2o da Lei no 8.072, de 25 de julho de 1990, que dispõe sobre os crimes hediondos, nos termos do inciso XLIII do art. 5o da Constituição Federal. Brasília, DF: Presidência da República, 2007. Disponível em: http://www.planalto.gov.br/ccivil_03/_ato2007-2010/2007/lei/111464. htm. Acesso em: 28 de junho de 2021 .

BRASIL. Lei n. ${ }^{0}$ 13.964, de 24 de dezembro de 2019. Aperfeiçoa a legislação penal e processual penal. Brasília, DF: Presidência da República, 2019. Disponível em: http://www.planalto.gov.br/ccivil_03/_ ato2019-2022/2019/lei/L13964.htm. Acesso em: 28 jun. 2021.

BRASIL. Ministério da Justiça e Segurança Pública. Departamento Penitenciário Nacional. INFOPEN, 2019.Disponível em: http://antigo. depen.gov.br/DEPEN/depen/sisdepen/infopen/relatorios-analiticos/br/ br. Acesso em: 7 jun. 2021.

BRASIL. Superior Tribunal de Justiça (3. Seção). Recurso Especial n. 1910240, Tribunal de Justiça do Estado de Minas Gerais. Relator: Ministro Rogério Schietti Cruz, Brasília, DF, julgado em 26 de maio de 2021. Disponível em:REsp1910240. Acesso em: 28 jun. 2021.

BRASIL. Superior Tribunal de Justiça (3. Seção). Recurso Especial n. 1918338, Tribunal de Justiça do Estado de Mato Grosso. Relator: Ministro Rogério Schietti Cruz, Brasília, DF, julgado em 26 de maio de 2021. Disponível em:https://processo.stj.jus.br/repetitivos/temas_repetitivos/pesquisa.jsp?novaConsulta $=$ true \&tipo_pesquisa $=$ T\&sg_clas$\mathrm{se}=$ REsp\&num_processo_classe=1910240. Acesso em: 28 jun. 2021. 
BRASIL. Superior Tribunal de Justiça. Súmula n. 439. Admite-se o exame criminológico pelas peculiaridades do caso, desde que em decisão motivada. Brasília, DF: Superior Tribunal de Justiça, 2010. Disponível em: https:/www.stj.jus.br/docs_internet/jurisprudencia/tematica/ download/SU/Verbetes/VerbetesSTJ.pdf. Acesso em: 28 jun. 2021.

BRASIL. Superior Tribunal de Justiça. Súmula n. 471. Os condenados por crimes hediondos ou assemelhados cometidos antes da vigência da Lei n. 11.464/2007 sujeitam-se ao disposto no art. 112 da Lei n. 7.210/1984 (Lei de Execução Penal) para a progressão de regime prisional. Brasília, DF: Superior Tribunal de Justiça, 2011. Disponível em: SSTJ. Acesso em: 28 jun. 2021.

BRASIL. Supremo Tribunal Federal (Tribunal Pleno). Habeas Corpus n. 82959, Tribunal de Justiça do Estado de São Paulo. Relator: Ministro Marco Aurélio Mello, Tribunal Pleno, Brasília, DF, julgado em 23 de fevereiro de 2006. Disponível em: HC82959. Acesso em: 28 jun. 2021.

BRASIL. Supremo Tribunal Federal (Tribunal Pleno). Habeas Corpus n. 111840, Tribunal de Justiça do Estado do Espírito Santo. Relator: Ministro Dias Toffoli, Brasília, DF, julgado em 14 de junho de 2012. Disponível em:http:/www.stf.jus.br/arquivo/cms/noticianoticiastf/anexo/hc111840dt.pdf. Acesso em: 28 jun. 2021.

BRASIL. Supremo Tribunal Federal. Súmula n. 698. Não se estende aos demais crimes hediondos a admissibilidade de progressão no regime de execução da pena aplicada ao crime de tortura. Brasília, DF: Supremo Tribunal Federal, 2003. Disponível em:http://www.stf.jus.br/ portal/jurisprudencia/menuSumarioSumulas.asp?sumula=1500. Acesso em: 28 jun. 2021.

BRASIL. Supremo Tribunal Federal. Súmula vinculante n. 26. Para efeito de progressão de regime no cumprimento de pena por crime hediondo, ou equiparado, o juízo da execução observará a inconstitucionalidade do art. $2^{\circ}$ da Lei 8.072, de 25 de julho de 1990, sem prejuízo de avaliar se o condenado preenche, ou não, os requisitos objetivos e subjetivos do benefício, podendo determinar, para tal fim, de modo 
fundamentado, a realização de exame criminológico. Brasília, DF: Supremo Tribunal Federal, 2006. Disponível em: http://stf.jus.br/portal/ jurisprudencia/menuSumarioSumulas.asp?sumula=3166. Acesso em: 28 de junho de 2021.

CAMARGO, Michele Demico. Progressão e Regressão de regime da pena privativa de liberdade: um comparativo entre a legislação vigente e o Projeto de Lei do Senado Federal no 236. Trabalho de Conclusão de Curso (Graduação) - Curso de Direito, Centro Universitário Eurípides de Marília - UNIVEM, 2014.

CINTRA, Adjair de Andrade. A contagem de prazos para o benefício da progressão de regime na execução penal e a jurisprudência dos tribunais superiores. In: Pacote Anticrime e temas atuais de processo penal. Cadernos Jurídicos da Escola Paulista da Magistratura, São Paulo, ano 22, n. 57, 2021.

CUNHA, Rogério Sanches. Pacote anticrime - lei 13.964/2019: comentários às alterações no CP, CPP e LEP. Salvador: Editora JusPodivm, 2020.

MARCÃO, Renato. Curso de execução penal. 17. ed. São Paulo: Saraiva Educação, 2019.

MENDES, Soraia da Rosa; MARTÍNEZ, Ana Maria. Pacote anticrime: comentários críticos à Lei 13.964/2019. São Paulo: Atlas, 2020.

MIRABETE, Júlio Fabbrini. Execução penal: comentários à lei $\mathrm{n}$. 7.210, de 11-7-1984. 12. ed. Revista e atualizada São Paulo: Atlas, 2014.

NUCCI, Guilherme de Souza. Curso de execução penal. 4. ed. Rio de Janeiro: Forense, 2021.

PIMENTEL, Manoel Pedro. O crime e a pena na atualidade. São Paulo: Revista dos Tribunais, 1983.

PRADO, Luiz Regis. et al. Direito de execução penal. 4. ed. rev. atual. e ampl. São Paulo: Editora Revista dos Tribunais, 2017. 
PRADO, Luiz Regis. et al. Curso de direito penal brasileiro. 11. ed. ver., atual. e ampl. São Paulo: Editora Revista dos Tribunais, 2011. v.1.

SANTOS, Marcos Paulo Dutra. Comentários ao pacote anticrime. Rio de Janeiro: Forense; São Paulo: MÉTODO, 2020.

Recebido em: 25/06/2021

Aprovado em: 10/08/2021 